\title{
Exxon Valdez and bioremediation
}

SIR - In response to the report by Bragg et al. ${ }^{1}$ on bioremediation of the Exxon Valdez oil spill in Prince William Sound, Alaska, in 1989, Henry Miller ${ }^{2}$ deplores the regulatory climate which he feels is responsible for suppressing the use of genetically engineered microorganisms (GEMs) for cleaning-up environmental contamination. However, stringent regulations are not the issue here. The real problem lies with GEM technology itself.

The concept of using genetically engineered 'super-bugs' to degrade something as complex as crude oil is seriously flawed. Crude oils are mixtures containing several hundred components including normal and branched-chain alkanes, substituted and unsubstituted cycloalkanes and mono- and polyaromatic hydrocarbons along with the so-called NSO (nitrogen, sulphur and oxygen containing) compounds such as cresols, pyridines, quinolines and benzothiophenes. The metabolic potential required to deal with this diverse array of chemical structures is considerable. Even if it were technically feasible to incorporate all the necessary genetic information into recombinant microorganisms, the burden of maintaining all these genes is likely to be so great as to make the recombinant strains noncompetitive in the natural environment. It is simplistic to think that introducing just a few genes (the limit of today's technology) into an organism will create a 'super-bug' that can degrade crude oils singlehandedly. This approach was tried in the mid-1970s (ref. 3), but no commercial products were forthcoming, primarily because crude oils are very effectively biodegraded by communities of naturally occurring indigenous microorganisms ${ }^{4}$.

Miller's justification for wanting to use genetically engineered microorganisms is that "naturally occurring microorganisms seem not to be up to the job" (of bioremediation). This is patently not true for crude oil and many organic contaminants in the environment. We have yet to come across an environment (soil, ground water, surface water, shoreline and so on) contaminated with petroleum hydrocarbons where a competent population of hydrocarbon-degrading microorganisms capable of cleaning the environment did not exist. To the best of our knowledge, this is also the experience of others working in this field ${ }^{4}$. On many occasions, cleaning takes place without the interference of man (natural attenuation) ${ }^{5}$. However, the biodegradation process is often limited by the size of the active microbial population that can be dependent on available mineral nutrients, such as nitrogen and phosphorus. Biodegradation can then be speeded up by the use of fertilizers, as Bragg et al. have demons- trated. Genetically engineered microorganisms are no different from wild types in their requirements for, among other things, nitrogen and phosphorus for growth.

Miller describes the Exxon approach to bioremediation as the "technology of the nineteenth century". Admittedly, "slopping" fertilizer on a beach to promote microbial activity does not have the 'hightech' sparkle of GEM technology. However, these natural tools do work and do lead to cost-effective solutions to many of our environmental contamination problems. We should exploit them.

\section{G. Lethbridge}

\section{H.J.J. Vits}

\section{R. J. Watkinson}

Environmental Research Department, Shell Research Ltd,

\section{Sittingbourne Research Centre,}

Sittingbourne, Kent ME9 8AG, UK

1. Bragg, J. R. et al. Nature 368, 413-418 (1994).
2. Miller, H. Nature 370, 244 (1994).

3. Friello, D. A., Mylroie, J. R. \& Chakrabarty, A. M. in Proc 3rd. Int. Biodegradation Symposium, Univ. Essex, UK (ed. Sharpley, J. M.) 205-214 (1976)

4. Atlas, R. M. \& Bartha, R. Adv. microbial Ecol. 12, 287-338 (1992)

5. Salanitro, J. P. Groundwater Monitoring Review, 150-161 (Fall, 1993)

\section{Bad example}

SiR - Dr Kary Mullis, who won the Nobel prize for chemistry in 1993, was invited to speak at the 28th Annual Scientific Meeting of the European Society for Clinical Investigation in Toledo during April. Just before the lecture, he told me he would not speak about the PCR but would tell his ideas about AIDS not being caused by the HIV virus. His talk was in style rambling and in content inappropriate for a public appearance of a leader of science, especially with several hundred young scientists present. His only slides (on what he called "his art") were photographs he had taken of naked women with coloured lights projected upon their bodies. $\mathrm{He}$ accused science of being universally corrupt with widespread falsification of data to obtain grants. Finally he impugned the personal honesty of several named scientists working in the HIV field.

His own explanation of the immunodeficiency syndrome was incoherent and insubstantial. As chairman, I stopped the lecture after half an hour and asked him to apply the scientific method to the problem, asking him to answer three specific questions about the transmission of AIDS to haemophiliacs and from mother to child. His reply was again inappropriate both intellectually and in style.

Mullis several times insisted that having won the Nobel prize gave him authority to speak. Surely the credible authority of a Nobel laureate should be confined to the subject for which he won the prize (in Mullis's case, chemistry). Mullis not only decreased the nobility of the prize but his attitude was, I believe, a potential corrupting influence on young scientists: among other things, for example, he claimed himself to have changed datapoints so as to make data-sets appear more significant by way of illustrating that the practice is a common one.

The council of the European Society for Clinical Investigation will not be inviting Mullis to speak at further meetings.

John F. Martin

(President)

European Society for Clinical

Investigation,

Bolognalaan 40,

3584 CJ Utrecht,

The Netherlands

\section{Strange but true}

SIR - In a recent issue of Nature (370, 107--8; 1994), Arthur C. Clarke described as "truly incredible - one might almost say eerie" the fact that the impacts of the largest fragments of comet ShoemakerLevy 9 coincided with the twenty-fifth anniversary of the Apollo 11 Moon landing. The fact that the impact of the largest fragment coincided, almost to the minute, with the twenty-fifth anniversary of the landing is actually only the centrepiece of a wider and more incredible set of coincidences: the first fragment of the comet hit Jupiter on 16 July (twenty-fifth anniversary of the launch of Apollo 11), and the final fragment hit on 22 July (twenty-fifth anniversary of Apollo 11's departure from Moon orbit). So the start, climax and end of the series of impacts coincided exactly with the start, climax and end (in the sense of departure from the Moon) of the Apollo 11 mission to the Moon.

A recent television programme informed me that the first SL9A impact, on 16 July, hit Jupiter at 4.18 p.m. US time (I am not sure which time standard that was). Today, I looked up the timings of the Apollo 11 mission in an encyclopaedia, and found the time of the Moon landing quoted as 4.18 p.m. US Eastern Daylight Time. I am a lifelong sceptic, but these coincidences interest and indeed startle me. I would like to invite those with easy access to the precise timings of all 21 cometary impacts, and the precise timings of key events of the Apollo 11 mission, to examine carefully just how "incredible" and just how "eerie" the coincidence is.

\section{Andrew Scott}

37 Mercat Green,

Kinrossie,

Perthshire PH2 6HT, UK 